\title{
Pengaruh Stabilitas Makro Ekonomi, Stabilitas Keamanan Dan Pertumbuhan Industri Strategis Terhadap Pertumbuhan Ekonomi
}

Oleh :

1) Guntur Eko Saputro,

Lecturer in Defence Ecomomics Indonesia, Defenese University Indonesia

Email : guntur_95@yahoo.com

\section{2) Meirinaldi}

Lecturer of Doctor Economic on Borobudur University Jakarta

Email : meirinaldi.2505@gmail.com

\section{ABSTRACT.}

The World Economic Forum in The Global Competitiveness Report 2016-2018, places Indonesia's competitiveness in the 41st rank of 138 countries with a Global Competitiveness index score of 4.52 on a scale of 1-7. Many factors determine the downgrade of Indonesia's competitiveness, including the low security and macroeconomic stability. The fundamental problems in economic development in Indonesia are the low level of welfare, unsustainable economic growth, and the inadequate development process of economic sectors.

The research aims to find empirical evidence in the framework of developing economic theory of development regarding the influence of macroeconomic stability structures, security stability and strategic industrial growth and its impact on economic growth. This study uses an explanatory method which aims to explain the causal relationship and test the hypothesis (hypothesis testing study). Secondary data in this study is the semester time series data for the period 2000-2018.

The research model is formulated as a recursive linear model in the form of a Cobb-Douglas production function and analyzed using multiple linear regression analysis with the Ordinary Least Square method. The results show that security stability, strategic industrial growth, and macroeconomic stability simultaneously influence economic growth.

Keywords: macroeconomic stability, security stability, strategic industrial growth and economic growth.

\section{PENDAHULUAN.}

Pertumbuhan ekonomi dipandang sebagai bagian terpenting dalam kebijakan ekonomi di negara maupun sistem ekonomi manapun. Karena pertumbuhan ekonomi menjadi salahsatu indikator meningkatnya kesejahteraan masyarakat. Meskipun demikian, ditengah pesatnya perkembangan 
dalam bidang industri, sains, dan revolusi teknologi, di negara-negara maju kemiskinan absolut dan sejumlah permasalahan ekonomi lainnya masih terjadi (Muttaqin 2018).

Pertumbuhan ekonomi yang tinggi dianggap belum stabil, bila basis partisipasi aktifnya timpang secara struktural, sektoral dan spasial. Dalam aspek lcehidupan ekonomi dan sosial-ekonomi, kesenjangan ini amat mudah memicu kecemburuan. Selanjutnya kecemburuan social. (Jurnal Ketahanan Nasional 2015.

Pertumbuhan ekonomi suatu bangsa terdapat tiga komponen utama yaitu kumulasi modal yang malalui suatu bentuk investasi, peralatan fisik dan sumber daya manusia (Todaro 2013). Pertumbuhan ekonomi adalah kenaikan kapasitas dalam jangka panjang dari Negara yang bersangkutan untuk menyediakan berbagai barang ekonomi kepada penduduknya (Sukirno, 2006:132)

Konsep keamanan mengalami pergeseran isu-isu keamanan tradisional menuju pada isu keamanan non-tradisional terutama pada people oriented yang berkembang menjadi multidimensional seperti ekonomi, sosial dan lingkungan yang berkaitan dan tidak terpisahkan satu sama lain (Buzan, 1991:433). Barry Buzan menyatakan terdapat lima dimensi yang saling terkait, yakni : military, political, economic, societal dan environmental.

Sebagai pertumbuhan ukuran kuantitatif kinerja perekonomian (Hakim, 2010: 12), pertumbuhan ekonomi (economic growth) mengukur pertambahan pendapatan riil, yaitu pendapatan yang dihitung pada harga yang konstan (Sukirno, 2013:56).

Keamanan ekonomi merupakan salah satu elemen utama dalam keamanan nasional. Saat berbicara mengenai keamanan nasional, kita tidak bisa melepaskan diri dari kemampuan ekonomi suatu negara. (Ronis, 2010). Keamanan ekonomi diperlakukan sebagai pemenuhan dasar kebutuhan manusia dan sebagai unsur yang sangat diperlukan bagi keamanan manusia (Mesjasz, 2008:578). Dimensi keamanan ekonomi telah melampaui apek penyediaan mata pencaharian individu dan juga meliputi kelangsungan dan keberlanjutan ekonomi masyarakat global (Tang, 2015: 49).

Teori ekonomi dapat digunakan untuk memecahkan masalah pilihan kebijakan pertahanan melalui 3 prinsip ekonomi, yaitu output akhir (final output), substitusi, dan kompetisi (Hartley, 2007: 7). Dengan prinsip output akhir, kebijakan pertahanan perlu fokus pada output akhir dari pertahanan yang diharapkan, yaitu: 
perdamaian, keamanan, perlindungan, atau output lainnya yang realistik.

Pertumbuhan ekonomi Indonesia masih belum stabil. Pada periode tahun 20122015, pertumbuhan ekonomi turun dari $6,0 \%$ menjadi $4,8 \%$; selanjutnya meningkat menjadi 5,2\% di tahun 2016 dan turun kembali menjadi 5,1\% di tahun 2017. Pola pertumbuhan ekonomi Indonesia tahun 2012-2017 cenderung paralel dengan pola pertumbuhan belanja pemerintah pusat.

Masih rendahnya stabilitas makroekonomi Indonesia. Berdasarkan The Global Competitiveness Report 2016-2017, stabilitas makroekonomi Indonesia masih di bawah beberapa negara ASEAN. Pada periode 2016-2017, dari 138 negara, stabilitas makroekonomi Indonesia berada di peringkat $30(\mathrm{GCI}=5,51)$, di bawah Filipina $(20$, GCI $=5,88)$; Singapura $(11$, $\mathrm{GCI}=6,15)$; dan Thailand $(13, \mathrm{GCI}=6,12)$ (WEF, 2017).

Masih rendahnya stabilitas keamanan di Indonesia. Berdasarkan The Global Competitiveness Report 2016-2017, dari 138 negara, stabilitas keamanan Indonesia berada di peringkat $115(\mathrm{GCI}=4,2)$ untuk biaya bisnis karena ancaman terorisme; peringkat $102(\mathrm{GCI}=3,9)$ untuk biaya bisnis karena ancaman kejahatan dan kekerasan; peringkat $108(\mathrm{GCI}=4,1)$ untuk kejahatan terorganisasi; dan peringkat 71
$(\mathrm{GCI}=4,3)$ untuk keandalan layanan kepolisian. Brunei Darussalam memiliki peringkat stabilitas keamanan yang lebih baik untuk keempat ukuran $(68$ [GCI $=$ $5,3], 50[\mathrm{GCI}=5,0], 40[\mathrm{GCI}=5,5]$, dan 57 $[\mathrm{GCI}=4,7])$, demikian pula Malaysia $(78$ $[\mathrm{GCI}=5,1], 60[\mathrm{GCI}=4,8], 59[\mathrm{GCI}=$ 5,1], dan 38 [GCI = 5,4]); dan Singapura $(46[\mathrm{GCI}=5,6], 7[\mathrm{GCI}=6,2], 7[\mathrm{GCI}=$ 6,4], dan 4 [GCI = 6,5]) (WEF, 2017).

Merujuk kepada Hartley, et al. (1995), secara makroekonomi, ekonomi pertahanan adalah suatu studi alokasi sumber daya, distribusi pendapatan, pertumbuhan ekonomi, dan stabilisasi yang diaplikasikan pada topik-topik yang berhubungan dengan pertahanan. Masalah dalam ekonomi pertahanan, sebagaimana dalam bidang ekonomi lainnya, adalah menentukan pilihan kebijakan pertahanan yang tepat dalam kondisi ketidak-pastian. (Hartley, 2007: 6)

Pertumbuhan industri strategis dalam pertahanan-keamanan hingga saat ini masih menghadapi kendala rendahnya kemampuan industri pertahanan nasional untuk memenuhi kebutuhan alat peralatan pertahanan-keamanan (Badan Pembinaan Hukum Nasional, 2011).

Menurut Born dan Flupi (dalam Perwita, 2006), Security Sector Reform dalam sistem negara demokrasi memiliki 
tiga konsepsi. Pertama, sebagai alat untuk menjamin stabilitas keamanan dan politik. Kedua, sebagai pendorong iklim ekonomipolitik, Ketiga, sebagai pendorong demokratisasi dan terbangunnya hubungan sipil-militer yang harmonis dan supremasi sipil.

Dalam sektor ekonomi, pendapatan sektoral berdasarkan pendekatan pengeluaran adalah jumlah nilai pengeluaran/pembelanjaan pada suatu sektor ekonomi yang dilakukan oleh sektor rumah tangga $(\mathrm{C})$, perusahaan / penanam modal (I), pemerintah (G) dan sektor luar negeri (NX: ekspor netto) atas dasar formula: $\mathrm{Y}=\mathrm{C}+\mathrm{I}+\mathrm{G}+\mathrm{NX}$ (Mankiw, 2003: 25).

\section{Ketidak-seimbangan permintaan} dengan penawaran barang/jasa yang memicu terjadinya inflasi masih tetap sejalan dengan stabilitas makroekonomi asalkan dapat dikendalikan sesuai tingkat inflasi yang ditargetkan. (Nanga, 2005: 241). Kenaikan harga dari satu atau dua barang/jasa saja tidak disebut inflasi, kecuali bila kenaikan tersebut meluas kepada atau mengakibatkan kenaikan sebagian besar dari harga barang/jasa lainnya (Budiono, 2009:167).

Kontribusi sektor industri dan jasa cenderung meningkat sejalan dengan meningkatnya pendapatan perkapita, sedangkan kontribusi sektor primer cenderung menurun sebagai konsekuensi dari meningkatnya kontribusi sektor industri dan jasa (Chenery, 1979: 17).

Penelitian bertujuan untuk menemukan bukti empirik dalam rangka pengembangan teori ekonomi pembangunan mengenai pengaruh struktur stabilitas makroekonomi, stabilitas keamanan dan pertumbuhan industri strategis serta dampaknya pada pertumbuhan ekonomi.

\section{BAHAN DAN METODE.}

Subjek dalam penelitian ini adalah Indonesia. Populasi penelitian adalah seluruh periode pembangunan di Indonesia. Sampel yang diteliti adalah periode pembangunan tahun 2000 - 2018 (19 tahun) dalam semesteran (38 semester). Metode pengambilan sampel (sampling) yang digunakan adalah convenience sampling sesuai ketersediaan data penelitian yang diperlukan. Data yang digunakan dalam pengukuran variabel penelitian merupakan data sekunder yang diperoleh dari Kementerian Pertahanan, Badan Pusat Statistik (BPS), dan World Economic Forum (WEF).

Variabel penelitian terdiri dari variabel bebas dan variabel terikat. Adapun variabel bebas adalah: Stabilitas makro ekonomi (X1), Pertumbuhan industri 
strategis $\left(\mathrm{X}_{2}\right)$,Stabilitas keamanan $\left(\mathrm{X}_{3}\right)$, dan variabel terikat pertumbuhan ekonomi (Y).

Desain penelitian yang digunakan adalah explanatory study atau hypothesis testing studi yang bertujuan untuk menjelaskan dan menguji hipotesis tentang hubungan antar variabel. Tehnik analisis statistik yang digunakan dalam penelitian ini adalah analisis regresi linear dalam model fungsi produksi Cobb-Douglas. Analisis regresi digunakan untuk mengkaji pola hubungan antara satu atau lebih variabel penyebab (eksogen) terhadap satu variabel akibat (endogen). Seluruh proses pengolahan dan analisis data dalam penelitian ini dilakukan dengan bantuan program komputer eViews 10 for Windows. Dalam analisis regresi dilakukan uji asumsi klasik yang dipersyaratkan. Uji asumsi tersebut meliputi: uji normalitas, uji multikolinieritas, uji heteroskedastisitas, dan uji autokorelasi.

Hipotesis statistik yang diuji untuk pengaruh Struktur Belanja PertahananKeamanan terhadap pertumbuhan industri strategis adalah sebagai berikut:

Ho: $\quad$ seluruh $\square_{\mathrm{ij}}=0$; artinya tidak terdapat pengaruh dari variabel penyebab terhadap variabel akibat.
Ha: $\quad$ minimal ada satu $\square_{\mathrm{ij}} \neq 0$; artinya terdapat pengaruh dari variabel penyebab terhadap variabel akibat.

Hipotesis statistik yang diuji untuk pengaruh Struktur Belanja PertahananKeamanan terhadap pertumbuhan industri strategis adalah sebagai berikut:

Ho: $\square_{\mathrm{ij}} \leq 0$; artinya tidak ada pengaruh positif dari suatu variabel penyebab terhadap variabel akibat.

Ha: $\square_{\mathrm{ij}}>0$; artinya terdapat pengaruh positif dari suatu variabel penyebab terhadap variabel akibat.

\section{HASIL DAN PEMBAHASAN.}

\section{Hasil Pengujian Asumsi}

Hasil pengujian asumsi klasik pada model pengaruh Stabilitas Makro ekonomi, Pertumbuhan Industri Strategis, dan Stabilitas Keamanan terhadap Pertumbuhan Ekonomi menunjukkan bahwa model telah memenuhi asumsi klasik yang dipersyaratkan, yaitu: berdistribusi normal, tidak terdapat situasi multikolinieritas, autokorelasi dan heteroskedastisitas. Pertimbangan perlunya uji asumsi klasik dalam model analisis regresi adalah untuk menghindarkan bias yang membuat hasil regresi tidak memiliki kemampuan untuk mengestimasi dengan baik atau bersifat BLUE (best linear unbiased estimator). 
2. Hasil Pengujian Hipotesis Pertumbuhan Industri Strategis, dan

Pengaruh.

Hasil pengujian hipotesis mengenai pengaruh Stabilitas Keamanan,
Stabilitas Makroekonomi terhadap Pertumbuhan Ekonomi dapat dilihat pada persamaan regresi di bawah ini.

$\operatorname{Ln} Y=b_{04}+b_{14} \operatorname{Ln} X 1^{\wedge}+b_{24} \operatorname{Ln} X 2^{\wedge}+b_{34} \operatorname{Ln} X 3^{\wedge}+e_{4}$

$\operatorname{Ln} Y=1,632+0,598 \operatorname{Ln} X 1^{\wedge}+1,343 \operatorname{Ln} X 2^{\wedge}+0,602 \operatorname{Ln~} X^{\wedge}+e_{4}$
$(\mathbf{0 , 6 1 1 )}$
$(3,100)$
$(1,642)$
$(3,155)$

$\mathbf{Y}=\mathbf{5 , 1 1 4} \cdot \mathbf{X} 1^{\wedge \mathbf{0 , 5 9 8}} \cdot \mathbf{X} \mathbf{2}^{\wedge \mathbf{1 , 3 4 3}} \cdot \mathbf{X} 3^{\wedge \mathbf{0 , 6 0 2}} \cdot \mathbf{u} 4 \quad\left(5,114=2,72^{1,632} ;\right.$ antilog natural $)$

Keterangan:

$\mathrm{X} 1=$ Stabilitas Makro Ekonomi

$\mathrm{X} 2=$ Pertumbuhan Industri Strategis

$\mathrm{X} 3=$ Stabilitas Keamanan

$\mathrm{X} 1^{\wedge}=$ estimasi Stabilitas Makro ekonomi dari fungsi $\mathrm{X}_{1}$

$\mathrm{X} 2^{\wedge}=$ estimasi Pertumbuhan Industri Strategis dari fungsi $\mathrm{X} 2$

$\mathrm{X}^{\wedge}{ }^{\wedge}=$ estimasi Stabilitas Keamanan dari fungsi $\mathrm{X}_{3}$

$\mathrm{Y}=$ Pertumbuhan Ekonomi

Tabel 1.

Persamaan Regresi Pengaruh Stabilitas Keamanan, Pertumbuhan Industri Strategis, dan Stabilitas Makroekonomi terhadap Pertumbuhan Ekonomi Dependent Variable: Y4

Method: Least Squares

\begin{tabular}{|c|c|c|c|c|}
\hline Variable & $\begin{array}{r}\text { Coefficie } \\
n t\end{array}$ & Std. Error & t-Statistic & Prob. \\
\hline $\mathrm{C}$ & 1.632215 & 12.02416 & 0.611205 & 0.5408 \\
\hline $\mathrm{X} 1^{\wedge}$ & 0.598357 & 0.193027 & 3.099854 & 0.0047 \\
\hline $\mathrm{X} 2^{\wedge}$ & 1.343133 & 0.817931 & 1.642110 & 0.1355 \\
\hline $\mathrm{X} 3^{\wedge}$ & 0.602145 & 0.190875 & 3.154651 & 0.0039 \\
\hline R-squared & 0.972151 & \multicolumn{2}{|c|}{ Mean dependent var } & 1.152254 \\
\hline Adjusted R-squared & 0.942512 & \multicolumn{2}{|c|}{ S.D. dependent var } & 0.284682 \\
\hline S.E. of regression & 0.069852 & \multicolumn{2}{|c|}{ Akaike info criterion } & 1.974668 \\
\hline Sum squared resid & 0.075465 & \multicolumn{2}{|c|}{ Schwarz criterion } & 1.486221 \\
\hline Log likelihood & 34.85644 & \multicolumn{2}{|l|}{ F-statistic } & 41.32335 \\
\hline Durbin-Watson stat & 1.865541 & \multicolumn{2}{|c|}{ Prob(F-statistic) } & 0.000000 \\
\hline
\end{tabular}

Besarnya responsivitas dari

Pertumbuhan Ekonomi atas perubahan

Stabilitas Makro ekonomi, Pertumbuhan

Industri Strategis, dan Stabilitas

Keamanan secara lebih rinci diuraikan sebagai berikut.

Konstanta: $\quad \mathrm{b}_{04}=1,632 ;$ jika logaritma natural seluruh variabel 
penyebab $=0(\mathrm{nol})$ maka nilai matematis dari logaritma natural Pertumbuhan Ekonomi sebesar 1,632 satuan. Koefisien regresi untuk Stabilitas Makro ekonomi: $\mathrm{b}_{14}=0,598 ;$ jika Stabilitas makro ekonomi naik 1 satuan, pada kondisi faktor lainnya bernilai konstan, maka Pertumbuhan Ekonomi cenderung naik 0,598 satuan. Sedangkan koefisien regresi untuk Pertumbuhan Industri Strategis: $b_{24}=1,343$; jika Pertumbuhan Industri Strategis naik 1 satuan, pada kondisi faktor lainnya bernilai konstan, maka Pertumbuhan Ekonomi cenderung naik 1,343 satuan. Adapun koefisien regresi untuk Stabilitas Keamanan: $\mathrm{b}_{34}=$ 0,602; jika Stabilitas Keamanan naik 1 satuan, pada kondisi faktor lainnya bernilai konstan, maka Pertumbuhan Ekonomi cenderung naik 0,602 satuan.

Besarnya pengaruh Stabilitas Makro ekonomi, Pertumbuhan Industri Strategis, dan Stabilitas Keamanan terhadap Pertumbuhan Ekonomi secara simultan ditunjukkan oleh koefisien determinasi yang disesuaikan (Adjusted $\mathrm{R}^{2}$ ), yaitu sebesar $94,3 \%$ dengan nilai statistik-F $=41,323$ dan $p$-value $=0,000$. Merujuk kepada nilai koefisien korelasi multipel yaitu sebesar $\mathrm{R}=0,971$ (sebagai akar dari Adjusted $\mathrm{R}^{2}$ ) menunjukkan bahwa pengaruh simultan dari Stabilitas makro ekonomi, Pertumbuhan Industri Strategis, dan Stabilitas keamanan terhadap Pertumbuhan Ekonomi tergolong sangat kuat, yaitu dengan nilai $\mathrm{R}$ antara 0,90 - 1,00 (Guilford, 1956: 145).

Dari hasil uji signifikansi diperoleh bahwa $p$-value dari statistik $\mathrm{F}$ adalah sebesar 0,000 yang lebih kecil dari $(\square=0,05)$. Hasil ini menunjukkan bahwa Stabilitas Makro ekonomi, Pertumbuhan Industri Strategis, dan Stabilitas Keamanan berpengaruh signifikan secara simultan terhadap Pertumbuhan Ekonomi pada taraf kesalahan 5\%. Dengan demikian, $\mathrm{H}_{0}$ ditolak dan hipotesis penelitian mengenai adanya pengaruh dari Stabilitas makro ekonomi, Pertumbuhan Industri Strategis, dan Stabilitas keamanan secara simultan terhadap Pertumbuhan Ekonomi diterima. Besarnya pengaruh, dengan kata lain juga menunjukkan besarnya variasi Pertumbuhan Ekonomi yang dapat dijelaskan oleh seluruh variabel penyebab secara simultan, yaitu sebesar Adjusted $\mathrm{R}^{2}=94,3 \%$. Sisa variasi, sebesar $5,7 \%$ atau 1 - Adjusted $\mathrm{R}^{2}$, dijelaskan oleh faktor lain yang tidak diteliti. 
Tabel 2.

Hasil Uji Pengaruh Simultan Stabilitas Keamanan, Pertumbuhan Industri Strategis, dan Stabilitas Makroekonomi terhadap Pertumbuhan Ekonomi

\begin{tabular}{|l|c|c|c|c|}
\hline \multicolumn{1}{|c|}{ Pengaruh Simultan } & $\mathbf{R}^{2}$ & $\begin{array}{c}\text { Adjusted } \\
\mathbf{R}^{2}\end{array}$ & F \\
& & & & \\
\hline $\begin{array}{l}\text { Stabilung } \\
\text { ekonomi, Pertumbuhan } \\
\text { Industri Strategis, } \\
\text { Stabilitas Keamanan }\end{array}$ & $\mathbf{9 7 , 2 \%}$ & $\mathbf{9 4 , 3 \%}$ & $\mathbf{4 1 , 3 2 3 ^ { * }}$ & $\mathbf{0 , 0 0 0 ^ { * }}$ \\
\hline
\end{tabular}

Keterangan:

$\mathrm{R}^{2}=$ koefisien determinasi multipel, Adjusted $\mathrm{R}^{2}=\mathrm{R}^{2}$ yang disesuaikan, ${ }^{*}=$ signifikan

Tabel di atas menunjukkan hasil uji yang signifikan yang menunjukkan adanya pengaruh positif dari Stabilitas Makro ekonomi $\left(\mathrm{X}_{1}^{\wedge}\right)$, Pertumbuhan Industri Strategis $\left(\mathrm{X}_{2}^{\wedge}\right)$, dan Stabilitas Keamanan $\left(\mathrm{X}_{3}^{\wedge}\right)$ secara simultan terhadap Pertumbuhan Ekonomi $\left(\mathrm{Y}^{\wedge}\right)$. Integrasi Stabilitas Makro ekonomi, Pertumbuhan Industri Strategis, dan Stabilitas keamanan meningkatkan efektivitas pencapaian Pertumbuhan Ekonomi.

\section{Pengaruh Stabilitas Makro} ekonomi secara parsial terhadap Pertumbuhan Ekonomi ditunjukkan oleh koefisien regresi $b_{14}=0,598$ dengan nilai statistik-t $=3,100$. Dari hasil uji signifikansi diperoleh nilai probabilitas kesalahan ( $p$-value) dari statistik t adalah sebesar 0,005 yang lebih kecil dari ( $\square=$ 0,05). Hasil ini menunjukkan bahwa Stabilitas Makro ekonomi berpengaruh positif signifikan secara parsial terhadap Pertumbuhan Ekonomi pada taraf kesalahan 5\%. Dengan demikian, $\mathrm{H}_{0}$ ditolak dan hipotesis penelitian mengenai adanya pengaruh dari Stabilitas makro ekonomi secara parsial terhadap Pertumbuhan Ekonomi diterima. Adanya arah pengaruh yang positif yang signifikan ini menunjukkan bahwa Stabilitas Makro ekonomi yang lebih tinggi cenderung menghasilkan Pertumbuhan Ekonomi yang lebih tinggi. Untuk ringkasnya, sebagaimana bentuk uraian di atas, pengaruh Stabilitas makro 
ekonomi, Pertumbuhan Industri Strategis, dan Stabilitas Keamanan secara parsial terhadap Pertumbuhan Ekonomi disajikan dalam tabel di bawah ini.

Tabel 3.

\section{Hasil Uji Pengaruh Parsial Stabilitas Makro ekonomi, Pertumbuhan Industri Strategis, dan Stabilitas Keamanan terhadap Pertumbuhan Ekonomi}

\begin{tabular}{|l|c|c|c|}
\hline \multicolumn{1}{|c|}{ Pengaruh Parsial } & bi3 & thitung & $p$-value \\
\hline Stabilitas Keamanan $\left(\mathrm{X}_{1}{ }^{\wedge}\right)$ & $\mathbf{0 , 5 9 8}$ & $\mathbf{3 , 1 0 0 ^ { * }}$ & $\mathbf{0 , 0 0 5}^{*}$ \\
\hline $\begin{array}{l}\text { Pertumbuhan Industri Strategis } \\
\left(\mathrm{X}_{2} \wedge\right.\end{array}$ & 1,343 & $\mathbf{1 , 6 4 2}^{\mathrm{ns}}$ & $\mathbf{0 , 1 3 6}^{\mathrm{ns}}$ \\
\hline Stabilitas Makroekonomi $\left(\mathrm{X}_{3^{\wedge}}\right)$ & $\mathbf{0 , 6 0 2}$ & $\mathbf{3 , 1 5 5 ^ { * }}$ & $\mathbf{0 , 0 0 4}$ \\
\hline
\end{tabular}

Keterangan:

$\mathrm{b}_{\mathrm{i} 3}=$ koefisien regresi, ${ }^{\text {ns }}=$ non-signifikan, ${ }^{*}=$ signifikan

Tabel di atas menunjukkan bahwa Stabilitas Makro ekonomi $\left(\mathrm{X}_{1}^{\wedge}\right)$ dan Stabilitas Keamanan $\left(\mathrm{X}_{3}{ }^{\wedge}\right)$ berpengaruh positif signifikan secara parsial terhadap Pertumbuhan Ekonomi (Y). Sedangkan Pertumbuhan Industri Strategis $\left(\mathrm{X}_{2}^{\wedge}\right)$ tidak berpengaruh positif signifikan secara parsial terhadap Pertumbuhan Ekonomi (Y).

Secara simultan, efek Stabilitas Makro ekonomi, Pertumbuhan Industri Strategis, dan Stabilitas keamanan adalah signifikan. Secara parsial, hanya Stabilitas Keamanan dan Stabilitas Makroekonomi saja yang berpengaruh positif signifikan secara parsial terhadap Pertumbuhan Ekonomi pada taraf kesalahan 5\%, sedangkan Pertumbuhan Industri Strategis tidak berpengaruh positif secara signifikan. Keberpengaruhan Pertumbuhan Industri Strategis dan Stabilitas Makroekonomi secara positif terhadap Pertumbuhan Ekonomi menunjukkan bahwa Stabilitas Keamanan dan Stabilitas Makroekonomi yang lebih tinggi, pada kondisi faktor lainnya tetap, mampu mendorong pemerintah untuk mencapai Pertumbuhan Ekonomi yang lebih tinggi. Hasil ini menunjukkan bahwa Stabilitas Keamanan dan Stabilitas Makroekonomi berperan penting dalam meningkatkan Pertumbuhan Ekonomi. 
Berdasarkan hasil analisis sebagaimana telah diuraikan di atas, variabel dominan dalam model adalah: Stabilitas Makroekonomi. Stabilitas Makroekonomi merupakan variabel dominan dibandingkan faktor lainnya yang secara konstruktif mempengaruhi Pertumbuhan Ekonomi. Dari ketiga faktor yang diteliti, Stabilitas Makroekonomi memiliki elastisitas (koefisien regresi) yang paling besar, demikian pula signifikansinya paling rendah. Hal ini menunjukkan bahwa Stabilitas Makroekonomi merupakan pendorong yang paling kuat dalam meningkatkan Pertumbuhan Ekonomi. Walaupun demikian, adanya pengaruh secara bersama-sama dari Stabilitas Keamanan, Pertumbuhan Industri Strategis, dan Stabilitas Makroekonomi mengisyaratkan bahwa peningkatan Stabilitas Keamanan, Pertumbuhan Industri Strategis, dan Stabilitas Makroekonomi yang bersifat konstruktif (berarah pengaruh positif) lebih memiliki kemampuan untuk meningkatkan Pertumbuhan Ekonomi.

Berdasarkan hasil penelitian, sebagai temuan, penelitian ini menunjukkan bahwa model pengaruh faktor-faktor yang diteliti terhadap Pertumbuhan Ekonomi mempunyai tingkat kesesuaian yang sangat tinggi, sebagaimana tercermin dari nilai koefisien determinasi. Walaupun demikian dalam kerangka solusi alternatif peningkatan Pertumbuhan Ekonomi, hasil pemodelan ini masih membuka peluang dilakukannya penelitian lanjutan untuk mengembangkan model yang tersusun atas faktor-faktor lain yang tidak diteliti yang secara teoritis juga memiliki pengaruh terhadap Pertumbuhan Ekonomi.

Sebagai model solusi peningkatan Pertumbuhan Ekonomi, hasil pengujian model menunjukkan bahwa upaya peningkatan Pertumbuhan Ekonomi dapat dilakukan melalui usaha-usaha peningkatan Stabilitas Makro ekonomi, Pertumbuhan Industri Strategis, dan Stabilitas Keamanan yang terbukti berarah pengaruh positif secara bersamasama. Kebijakan pembangunan yang relevan dalam peningkatan Pertumbuhan Ekonomi adalah peningkatan Stabilitas makro ekonomi, Pertumbuhan Industri Strategis, dan Stabilitas keamanan secara sinergik dan berkesinambungan.

\section{KESIMPULAN}

Stabilitas Makro ekonomi, pertumbuhan industri strategis, dan stabilitas keamanan berpengaruh secara simultan terhadap pertumbuhan ekonomi. 


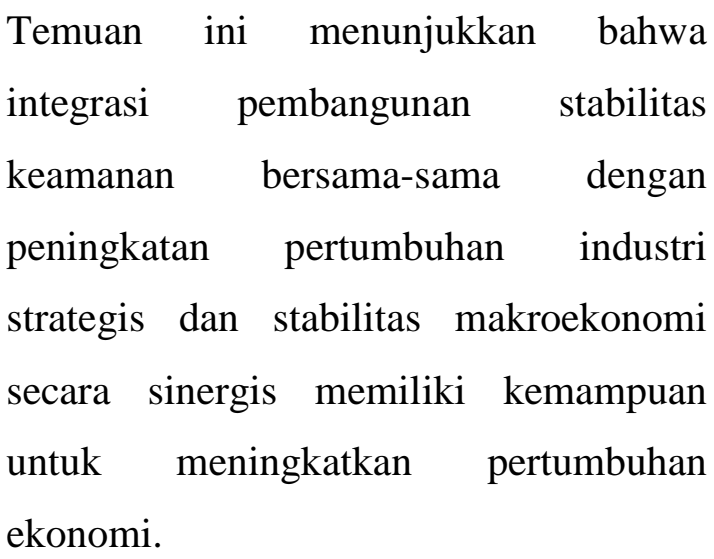

Secara parsial, pertumbuhan ekonomi lebih dipengaruhi oleh pengaruh positif yang signifikan dari stabilitas makroekonomi dan stabilitas keamanan daripada pertumbuhan industri strategis. Temuan ini menunjukkan bahwa peningkatan stabilitas keamanan dan stabilitas makroekonomi yang didukung dengan peran industri strategis yang lebih efektif, dengan memperhatikan keterkaitan antara ketiganya, memiliki kemampuan untuk meningkatkan pertumbuhan ekonomi. Diantara faktorfaktor pertumbuhan ekonomi yang diteliti, stabilitas makroekonomi merupakan determinan dominan bagi pertumbuhan ekonomi.

\section{DAFTAR PUSTAKA}

Buzan, Barry, 1991, 'New Patterns of Global Security in the TwentyFirst Century'. International Affairs, Vol.67 No.3.
Badan Pembinaan Hukum Nasional, 2011. Pengembangan dan Pemanfaatan Industri Strategis untuk Pertahanan. Badan Pembinaan Hukum Nasional, Kementerian Hukum dan Hak Asasi Manusia. Jakarta.

Budiono. 2009. Ekonomi Moneter. Penerbit BPFE UGM. Yogyakarta.

BPS. 2003. Buletin Statistik Bulanan Desember. BPS. Jakarta

Chenery, Hollis, 1979. Structural Change and Development Policy. Oxford University Press

Guilford, J.P. 1956. Fundamental Statistic for Psychology and Education, McGraw-Hill.

Hartley, Keith. 2007. Defense Economics: Achievements and Challenges. Asian Proceeding of the $10^{\text {th }}$ Annual International Conference on Economics and Security.

Hakim, Abdul. 2010. Ekonomi Pembangunan. Yogyakarta: Ekonisia Kampus Fakultas Ekonomi UII.

Hartley, Keith; Sandler, Todd. 1995. Handbook of Defense Economics. Volume I. Elsevier Science.

Jurnal Ketahanan Nasional (2015) 
Penciptaan Dan Pemeliharaan

Keamanan Dan Perdamaian

Dalam Menghadapi Era

Globalisasi• Diiviensiekonomi

Muttaqim R. (2018) Maro, Jurnal

Ekonomi Syariah dan

Bisnis Pertumbuhan Ekonomi

dalam Perspektif Islam Economic

Growth in Islamic Perspective

Mesjasz, Czeslaw, 2008, 'Economic

Security,' dalam Hans Günter

Brauch (eds.), Globalization and

Environmental Challenges, Berlin

: Springer Berlin Heidelberg, hlm.

569-580.

Nanga, Muana. 2005. Makro Ekonomi:

Teori, Masalah dan Kebijakan.

Rajawali Pers. Jakarta.

Perwita, Anak Agung Banyu. 2006.

Pengantar Rekam Jejak Proses

Security Sector Reform Indonesia

2000-2005. Propatria Institute,

Jakarta.

Ronis, Sheila R, 2010, 'Economic

Security Neglected Dimension of

National Security?', Center for
Strategic Conferencing Institute

for National Strategies Studies,

National Defense University Press

Sukirno, Sadono. (2006). Makro

Ekonomi Teori Pengantar.

Jakarta: Raja Grafindo Persada.

Sukirno, Sadono. 2013. Ekonomi

Pembangunan: Proses, Masalah

dan Dasar Kebijakan. Edisi

Kedua. Cetakan kelima. Jakarta:

Kencana Prenada Media Group

Todaro, Michael P. and Smith,

Stephen C, (2003), Economic

Development, UK : Pearson

Education Limited.

Tang, Siew Mun, 2015, 'Rethinking

Economic Security in A

Globalized World,' Contemporary

Politics, terbitan online dari

Routledge Taylor \& Francis.

Tickner. 